Research note

\title{
New records of Erichsonella attenuata (Isopoda: Valvifera: Idoteidae) in the Gulf of Mexico
}

\author{
Nuevos registros de Erichsonella attenuata (Isopoda: Valvifera: Idoteidae) en el golfo de México \\ José Luis Bortolini-Rosales $^{\mathrm{a}, *}$, Hugo Reyes-Aldana ${ }^{\mathrm{a}}$, Mario A. Gómez-Ponce ${ }^{\mathrm{b}}$ \\ ${ }^{a}$ Departamento de Biología Comparada, Facultad de Ciencias, Universidad Nacional Autónoma de México, Circuito Exterior s/n, \\ Colonia Copilco El Bajo, 04510 México, D.F., Mexico \\ b Instituto de Ciencias del Mar y Limnología, Estación El Carmen, Universidad Nacional Autónoma de México, \\ Km. 9.5 carretera Carmen-Puerto Real, 24157 Ciudad del Carmen, Campeche, Mexico
}

Received 22 April 2015; accepted 12 November 2015

Available online 6 May 2016

\begin{abstract}
Erichsonella attenuata is an isopod species distributed in the Western Atlantic region of the Gulf of Mexico and is associated with sea-grass beds composed of Ruppia maritima, Halodule wrightii and Thalassia testudinum. In the Gulf of Mexico, this isopod species is found only along the USA coasts, in Texas and Florida. The aim of this work is to report, for the first time, the presence of E. attenuata along Mexican coasts, particularly in the Tamiahua and Términos lagoons in the states of Veracruz and Campeche, respectively. These are the most southern records for the Gulf of Mexico, showing that this species expands its coverage virtually to the entire coast of the Gulf of Mexico. The specimens were deposited in the Colección Nacional de Crustáceos, Instituto de Biología, Universidad Nacional Autónoma de México.

All Rights Reserved (C) 2016 Universidad Nacional Autónoma de México, Instituto de Biología. This is an open access item distributed under the Creative Commons CC License BY-NC-ND 4.0.
\end{abstract}

Keywords: Erichsonella attenuata; New record; Tamiahua lagoon; Términos lagoon

\section{Resumen}

Erichsonella attenuata es una especie de isópodo distribuida en el Atlántico oeste del golfo de México y está asociada a pastos marinos compuestos por Ruppia maritima, Halodule wrightii y Thalassia testudinum. En el golfo de México, en las costas de los EE. UU., este isópodo se encuentra en Texas y Florida. El objetivo de este trabajo es registrar por primera vez la presencia de E. attenuata en costas mexicanas, particularmente en las lagunas de Tamiahua y Términos en los estados de Veracruz y Campeche, respectivamente. Estos registros son los más sureños en el golfo de México y muestran que esta especie se expande en cobertura virtualmente a todas las costas del golfo de México. Los ejemplares fueron depositados en la Colección Nacional de Crustáceos, Instituto de Biología, Universidad Nacional Autónoma de México.

Derechos Reservados (C) 2016 Universidad Nacional Autónoma de México, Instituto de Biología. Este es un artículo de acceso abierto distribuido bajo los términos de la Licencia Creative Commons CC BY-NC-ND 4.0.

Palabras clave: Erichsonella attenuata; Nuevo registro; Laguna de Tamiahua; Laguna de Términos

Erichsonella Richardson, 1900 is a shallow-water American genus of isopod, inhabiting tropical and warm temperate regions found on algae, mud flats, sea grasses and oyster beds (Pirés, 1984). Erichsonella attenuata (Harger, 1874) vary in colour,

\footnotetext{
* Corresponding author.

E-mail address: jlbr@ciencias.unam.mx (J.L. Bortolini-Rosales).

Peer Review under the responsibility of Universidad Nacional Autónoma de México.
}

from amber to brown and both male and female individuals may have darker spots on the dorsal and ventral areas, with a maximum total length of $18.4 \mathrm{~mm}$; on average adult males are longer than females and are known from the New Jersey, Connecticut, Miami, Florida and Mississippi (Pirés, 1984).

In the Gulf of Mexico, E. attenuata is present along the Texas coast, in the intertidal zone from $0 \mathrm{~m}$ to $20 \mathrm{~m}$ depth (Boström \& Mattila, 2005; Kensley \& Schotte, 1989; Pirés, 1984). According to the division of the Gulf of Mexico proposed by Felder, Camp, 


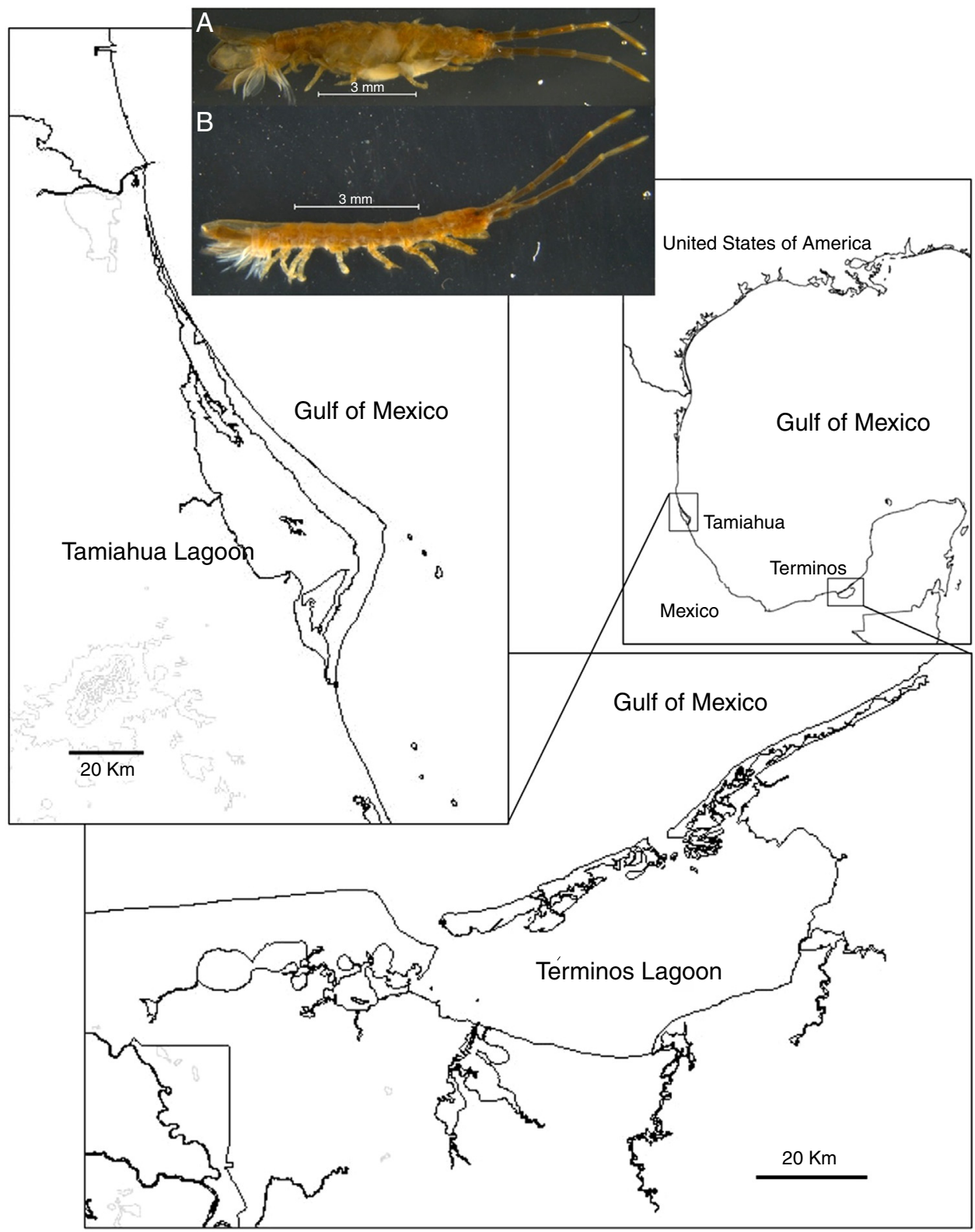

Figure 1. Map showing Tamiahua and Términos lagoons in Mexican coast in the Southern, Southwestern and East-Northeast regions, respectively, of the Gulf of Mexico. Inset: Erichsonella attenuata (Harger, 1874). (A) Ovigerous female and (B) male.

and Tunnell (2009), the species is observed in the North-East and North-West regions, delimited in the South by parallel $25^{\circ} \mathrm{N}$.

This isopod species has been observed in some sites of the Western Atlantic part of the Gulf of Mexico (Kensley, Nelson, \& Schotte, 1995) and it is associated with sea-grass beds (Boström \& Mattila, 1999; Darcy \& Eggleston, 2005; Sheridan, 2004), such as Ruppia maritima, Halodule wrightii and Thalassia testudinum (Boström \& Mattila, 2005; Kensley et al., 1995). In the Indian River Lagoon, Florida, E. attenuata is one of the 3 most common invertebrate species found in $H$. wrightii beds and it is an important epiphytic grazer. It is also an important food resource for higher trophic levels, occasionally consumed extensively by sea grass-associated fish (Ryer \& Orth, 1987).

In this paper, the presence of E. attenuata is reported for the first time in Mexican coasts, in the Tamiahua Lagoon,
Veracruz and in the Términos Lagoon, Campeche (Fig. 1). Tamiahua is located in the West-Southwest (WSW) region of the Gulf of Mexico and the Términos Lagoon is located in the South-Southwest (SSW) region (Felder et al., 2009). Schotte, Markham, and Wilson (2009), according to regions mentioned by Felder et al. (2009), reported E. attenuata in the NorthNortheast (NNE) and the East-Northeast (ENE) regions of the Gulf of Mexico.

In the Tamiahua Lagoon 2,315 individuals of E. attenuata were collected with scoop nets (mesh aperture $1.6 \mathrm{~mm}$ ) from July 2010 to August 2011, between $21^{\circ} 25^{\prime} 46^{\prime \prime}-21^{\circ} 28^{\prime} 46^{\prime \prime} \mathrm{N}$ and $97^{\circ} 24^{\prime} 22^{\prime \prime}-97^{\circ} 26^{\prime} 57^{\prime \prime} \mathrm{W}$. These were associated with $H$. wrightii, which is present on the eastern coasts of America, including Alabama, Florida, Louisiana, Mississippi, and North Carolina (USA), the east coast of Mexico, the West Indies (Cuba, 
Table 1

Basic biological information of the collected material of Erichsonella attenuata (Harger, 1874). Morphological nomenclature is according to Pirés (1984) (Tam, Tamiahua; Ter, Términos).

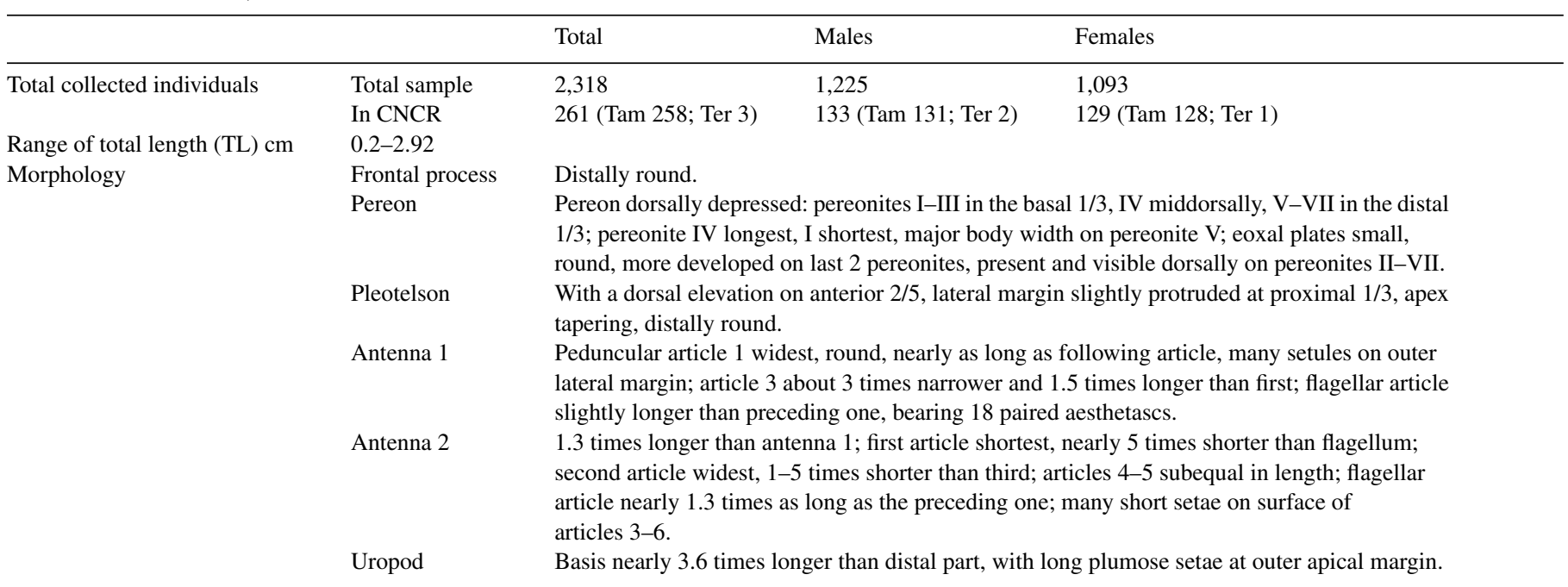

Jamaica, Haiti, Dominican Republic and Puerto Rico), Central America (Belize, Guatemala, Nicaragua), and South America (Venezuela and Brazil) (Ferguson, Pawlak, \& Wood, 1993; Haynes, 2000).

In the Términos Lagoon, E. attenuata individuals were collected with a Seagrove sledge net (mesh aperture $0.8 \mathrm{~mm}$ ). Only 3 individuals were collected, 1 isopod per month, in December 2012 and in the months of May and July 2013 in the same sampling station $\left(18^{\circ} 30^{\prime} 13^{\prime \prime} \mathrm{N}, 91^{\circ} 41^{\prime} 58^{\prime \prime} \mathrm{W}\right)$. They were associated with T. testudinum beds, which are present in the Caribbean and the Gulf of Mexico. The northernmost station of T. testudinum is in San Sebastian Inlet, near Cape Kennedy, Florida, in the East, Bermuda Island; while in Central America, it is present in British Honduras, Costa Rica, Panama and Venezuela (Hartog, 1970).

These data suggest that E. attenuata may be widely distributed in the Gulf of Mexico, extending its original distribution from the coasts of Texas, USA to at least the coasts of Campeche, Mexico. The first report was from $26^{\circ} \mathrm{N}$ and the last is reaching $18^{\circ} \mathrm{N}$. Thus, the current distribution of E. attenuata is from the state of Connecticut in the USA, to the state of Campeche in Mexico, covering the North-Western Atlantic coast of Florida and virtually the entire Gulf of Mexico.

The material examined and identified as E. attenuata was 2,318 individuals; 2,315 collected in Tamiahua Lagoon, Veracruz and 3 in Términos Lagoon, Campeche; some individuals were deposited in the Colección Nacional de Crustáceos of the Instituto de Biología, Universidad Nacional Autónoma de México; 258 from Tamiahua Lagoon with catalogue number: CNCR 26120 and from Términos Lagoon, 3 with catalogue numbers: CNCR 28796; CNCR 28797; and CNCR 28798. According to Pirés (1984), of the 6 species of the genus, $E$. attenuata presents the greatest number of primitive characters. In Table 1 we present basic morphological data of the collected material from the 2 sites including number of males and females, range of total length, morphology of the frontal process, pereonites, pleotelson, antenna 1 , antenna 2 , and uropod.
Special thanks to Ricardo Gaspar and Alan González, undergraduate Biology students of the School of Sciences, Universidad Nacional Autónoma de México for the field work in Tamiahua, and to Hernan Álvarez Guillén and Andrés Reda Deara for their field work in the Términos Lagoon. We also thank Luis and Jorge Luis Díaz, enthusiastic fishermen of the Tamiahua Lagoon, Veracruz; Verónica Aguilar (FC, UNAM) for editing the map, and Dr. Fernando Álvarez, who was in charge of identifying the biological samples.

\section{References}

Boström, C., \& Mattila, J. J. (1999). The relative importance of food and shelter for seagrass associated invertebrates: a latitudinal comparison of habitat choice by isopods grazers. Oecologia, 120, 162-170.

Boström, C., \& Mattila, J. J. (2005). Effects of isopod grazing: an experimental comparison in temperate (Idotea balthica, Baltic Sea, Finland) and subtropical (Erichsonella attenuata, Gulf of Mexico, USA) ecosystems. Crustaceana, 78, 185-200.

Darcy, M. C., \& Eggleston, D. B. (2005). Do habitat corridors influence animal dispersal and colonization in estuarine systems? Landscape Ecology, 20, 841-855.

Felder, D. L., Camp, D. K., \& Tunnell, W., Jr. (2009). An introduction to Gulf of Mexico biodiversity assessment. In D. L. Felder, \& D. K. Camp (Eds.), Gulf of Mexico origin, waters, and biota. Biodiversity (Vol. 1) (pp. 1-13). College Station: Texas A\&M University Press.

Ferguson, R. L., Pawlak, B. T., \& Wood, L. L. (1993). Flowering of the seagrass Halodule wrightii in North Carolina, USA. Aquatic Botany, 46, 91-98.

Hartog, C. D. (1970). The sea-grasses of the world. Verhandelingen der Koninklijke Nederlandsche Akademie van Wetenschappen te Amsterdam, Afdeeling Natuurkunde, 59, 1-276.

Haynes, R. R. (2000). Cymodoceacea: manatee-grass family. In Flora of North America Editorial Committee (FNAE) (Ed.), Flora of North America: North of Mexico, Volume 22: Magnoliophyta: Alismatidae, Arecidae, Commelinidae (in part), and Zingiberidae (pp. 86-89). New York: Oxford University Press.

Kensley, B., Nelson, W. G., \& Schotte, M. (1995). Marine isopod biodiversity of the Indian River lagoon, Florida. Bulletin of Marine Science, 57, 136-142.

Kensley, B., \& Schotte, M. (1989). Guide to the marine isopod crustaceans of the Caribbean. Washington, DC: Smithsonian Institution Press. 
Pirés, S. A. M. (1984). Taxonomic revision and phylogeny of the genus Erichsonella with a discussion on Ronalea (Isopoda, Valvifera). Journal of Natural History, 18, 665-683.

Ryer, C. H., \& Orth, R. J. (1987). Feeding ecology of the Northern Pipefish, Syngnathus fuscus, in a seagrass community of the lower Chesapeake Bay. Estuaries, 10, 330-336.
Sheridan, P. (2004). Comparison of restored and natural sea grass beds near Corpus Christi, Texas. Estuaries, 27, 781-792.

Schotte, M., Markham, J. C., \& Wilson, G. D. F. (2009). Isopoda (Crustacea) of the Gulf of Mexico. In D. L. Felder, \& D. K. Camp (Eds.), Gulf of Mexico origin, waters and biota (1) (pp. 973-986). College Station: Texas A\&M University Press. 